\title{
Position of the People's Republic of China Towards the Crisis in Libya in 2011
}

\author{
Postawa Chińskiej Republiki Ludowej \\ wobec kryzysu w Libii w 2011 roku
}

\section{- Abstrakt •}

Przedmiotem analizy jest postawa Chińskiej Republiki Ludowej wobec kryzysu w Libii w 2011 roku. Problem ten rozpatrywany jest z uwzględnieniem okoliczności dwustronnych i wielostronnych. W artykule omówiono zagadnienia takie jak współpraca Chin z Libią przed kryzysem oraz działania Pekinu na kolejnych jego etapach. Dotyczy to głównie ewolucji postawy Chin w kwestii nakładania i wdrażania sankcji wobec Libii oraz ewolucji postawy wobec politycznej reprezentacji ugrupowań rebelianckich. Rozważania prowadzone są w kontekście stosowania się przez Pekin do tradycyjnych zasad polityki zagranicznej ChRL i podejścia do koncepcji „Odpowiedzialność za ochronę”. Przypadek kryzysu w Libii pokazał, że Chiny nie mają wypracowanej spójnej strategii działania wobec wewnętrznych konfliktów o charakterze zbrojnym generujących klęski humanitarne.

Słowa kluczowe: Chińska Republika Ludowa; Libia, kryzys w Libii; polityka zagraniczna Chin; „Odpowiedzialność za ochronę”

\section{- Abstract •}

The subject of the analysis is the attitude of the People's Republic of China towards the crisis in Libya in 2011. The problem is considered taking into account both the bilateral China-Libya and multilateral situation at the time. The paper discusses issues such as China's cooperation with Libya before the crisis and Beijing's actions at consecutive stages of the crisis, focusing mainly on the evolution of China's position towards the question of imposing and implementing sanctions against Libya as well as towards the political representation of the Libyan rebel groups. The discussion is presented in the context of Beijing's compliance with its traditionally professed foreign policy principles and its attitude towards the concept of "Responsibility to Protect". The case of the Libyan crisis has shown that China does not have a coherent strategy for dealing with internal military conflicts that generate humanitarian disasters in foreign states.

Keywords: People's Republic of China; Libya; crisis in Libya; China's foreign policy; "Responsibility to Protect" 


\section{Introduction}

In 1954, the leaders of the People's Republic of China formulated five basic principles of Chinese foreign policy which still remain valid today, namely: mutual respect for sovereignty and territorial integrity, mutual non-aggression, non-interference in each other's internal affairs, equality and mutual benefit, and peaceful coexistence (Nathan). Beijing is in favor of every state being able to independently choose its reigning socio-political system and the path of economic development. This approach is rooted mainly in historical experience and supported by political reasoning. China has for centuries been a victim of external colonial interference, which has birthed its firm opposition to such policies pursued by the great powers. Currently, Beijing is seeking to complete the process of state unification and maintain territorial integrity of China. The Chinese authorities are violently reacting to any external action supporting the independence aspirations of Taiwan, Tibet or Xinjiang. In addition, the PRC is now one of the last formally socialist countries in the world with a one-party system. The state authorities, selected from among members of the Communist Party of China (CPC), fight the Chinese democratic movements supported by the West.

Beijing opposes the use of military force in resolving internal state conflicts by the international community. China believes that this usually leads to their exacerbation and escalation. In principle, the PRC is also quite restrained in imposing economic and political sanctions on other states, as Chinese leaders believe that the best way to resolve internal conflicts are diplomatic methods, in the form of mediation, persuasion and incentives. Introduction of sanctions, especially those of a military nature, is perceived only as a truly last resort. China also supports that such sanctions can only be imposed by the United Nations (Junbo, Zhimin, 2016). However, Beijing does recognize the importance of peaceful use of armed forces in stabilizing post-conflict situations. For this reason, the country is the largest contributor of troops to UN peacekeeping missions. However, it should be noted that deployment of UN forces requires the consent of the host country, and thus remains in line with the principles laid out by Chinese authorities.

The attitude of China towards humanitarian interventions within the framework of the "Responsibility to Protect" concept is quite particular. In situations of genocide, ethnic cleansing, war crimes and crimes against humanity, permanent members of the UN Security Council have a special responsibility to stop such atrocities (Falk, 2015). Beijing formally supports the idea of R2P, but in practice China is generally not willing to conduct military operations to protect the civil population if there is no agreement from the host state. For this reason, the PRC 
opposed, inter alia, military interventions in Kosovo, Sudan, Burma or Syria, in which deep humanitarian crises occurred (Harnisch, 2016). China advocated diplomatic solutions that were supposed to lead to peace and allow for a traditional peacekeeping mission as a result.

This paper aims to present and evaluate the attitude of the People's Republic of China towards the crisis in Libya in 2011. The issue is considered both from a bilateral China-Libya and multilateral point of view. The main thesis posited by the author is that the Chinese approach to the Libyan crisis has shown that Beijing does not have a coherent strategy for action against internal armed conflicts generating humanitarian disasters in foreign states. The professed basic principles of its foreign policy are treated by China in an ambivalent way, depending on the impact conforming with them would have on Beijing's strategic interests and on international circumstances at the time. The article uses the method of text source analysis.

\section{Cooperation of the PRC with Libya before the Crisis}

Cooperation between the People's Republic of China and Libya was focused on the economy. In the 1980s, China provided Libya with development aid in the domain of agriculture, but its scope and thus impact were limited. The arms trade was more important as the Middle East region was at that time an important recipient of Chinese arms and military equipment. This market was particularly important in the 1980s, when the People's Republic of China sold weapons worth more than USD 9 billion to Middle East states. The main purchasers of Chinese military equipment in the region were Iran, Iraq and Egypt, but the list of recipients included also Saudi Arabia, Syria and Libya (Shichor, 2017). Among the weapons purchased by Libya were, inter alia, ballistic missiles. Later, the sale of weapons to Libya was prohibited due to economic sanctions imposed on this country by the UN for the terrorist attack on a plane flying over Lockerbie in Scotland. It is worth mentioning that the Chinese nuclear missile design was also sold to Libya. The transaction happened through the intermediary of Islamabad, friendly with Beijing, and the design was sold to Tripoli by the head of the Pakistani nuclear program - Abdul Qadeer Khan (Hoyt, 2016). China, however, was attempting to persuade Libya to abandon the nuclear program and cease its support for terrorist activities, in exchange promising Beijing's help in abolishing economic sanctions, what finally took place in 2003 (Olimat, 2014). Limited economic cooperation in the 1980s and diplomatic support provided at the beginning 
of the $21^{\text {st }}$ century created good conditions for strengthening trade cooperation between these two states.

Following the lifting of economic sanctions on Libya, the PRC became involved in a number of construction projects in that country. China also invested significant resources in oil and gas exploration and development of crude oil extraction infrastructure. A new boost to the economic cooperation was provided in 2008, when China signed with Libya contracts for engineering services, construction and other services worth USD 10.05 billion. Libya was among the three largest outbound investment destinations of the People's Republic of China that year (Copper, 2016). In total, from the beginning of 2008 to March 2011, 75 Chinese enterprises - including 13 state-owned companies - became involved in 50 projects located in Libya, worth in total about USD 18.8 billion and employing 36,000 Chinese workers (Junbo, Méndez, 2015). The Chinese oil imports from Libya also increased considerably. Between 2007 and 2010, the share of Libyan oil in total Chinese imports of this raw material increased from 1.8 to 3.1\% (Zweig, 2016). From the perspective of Libyan economy in 2010, China accounted for as much as $11 \%$ of total exported oil. However, some perturbations emerged in cooperation between the states in this sector in 2009, when the Libyan government canceled the contract for acquisition by China National Petroleum Corporation of USD 406 million worth of shares in the Canadian oil company Verenex (Sotloff, 2012).

Chinese exports to Libya were growing dynamically during that period. In 2010, the PRC was the second most important supplier of goods to Libya, after its postcolonial patron - Italy. Deliveries from China accounted for $10.5 \%$ of total Libya imports (Sotloff, 2012). The total value of trade between the two countries at the time was USD 6.6 billion (Erian, 2012). Despite the sharp increase in China's economic involvement in Libya, the dominant position in this market was still maintained by western companies what was visible, among others, in the energy and weapon sectors, considered crucial for China. Nevertheless, the Libyan authorities were declaring their will to further tighten the economic exchange with China (Olimat, 2014).

In the first decade of the $21^{\text {st }}$ century, the PRC also perceived Libya as one of the states through which it could promote the concept of South-South cooperation in Africa. Since 2008, China has participated, inter alia, in the Libya-financed development project "Malibya" worth USD 55 million. Its goal was to increase Mali's rice production capacity by $20 \%$. Construction of irrigation systems and delivery of various types of rice was sub-contracted to Chinese counterparties. With the fall of the regime of Mu'ammar Gaddafi, the project was stopped indefinitely 
(Gaudreau, 2016), what translated into losses for Chinese enterprises and reduced the possibility of exports of irrigation technologies and rice seeds in this part of Africa. Looking more broadly, it has also rendered the promotion of the "SouthSouth" concept difficult, and thus slowed the development of China's economic and political influence on the continent.

\section{China's Attitude at the First Stages of the Crisis in Libya}

The "Arab Spring" revolution which began in North Africa in December 2010 was perceived in Beijing as a sure way to destabilize the region. The Chinese Communist Party (CCP) was also concerned about the slogans of democratization of political life. Beijing did not support this social movement as the authorities believed it could jeopardize its vital interests. The revolutionary mood spread from Tunisia and Egypt to Libya, and on February 15, 2011 the first mass protests against the regime of Mu'ammar al-Gaddafi broke out. On February 21, the government troops and hired mercenaries brutally pacified anti-government demonstrations in Tripoli. This started a civil war in which the army tried to stop and pacify the offensive operations of the rebels.

During the crisis, Beijing primarily made its attitude dependent on the stance of the international community, in particular of the Arabic and African regional organizations. The People's Republic of China wanted to strengthen its position as leader of the developing world, which was intended to facilitate promotion of the "South-South" concept. As these organizations expected decisive action, on February 26, 2011, China gave its support for the UN Security Council resolution no 1970. The document demanded of Libyan authorities to immediately cease the use of violence and start fulfilling the government's responsibility to protect its own citizens. It called upon Libya for compliance with international humanitarian law, human rights and refugee rights. Investigation of the crimes committed in Libya during the crisis was entrusted to the International Criminal Court. The UN Council also decided to freeze the assets of people directly related to the Libyan regime, and imposed on the international community the obligation to comply with the embargo on supplying, selling and transferring weapons to Libya (United Nations, 2011a). The Permanent Representative of the PRC at the UN - Li Baodong explained after the vote that the position of Beijing was influenced by the unique situation in Libya and the concerns and opinions of the Arab and African states (Duggan, 2016). Support for the resolution was to stem from the "greatest urgency to secure the immediate cessation of violence, avoid further bloodshed 
and civilian casualties". China, however, advocated peaceful methods of ending the crisis, including declaring its support for political dialogue between parties to the conflict (Carvin, 2011).

The outbreak of civil war in Libya seriously threatened Chinese economic entities and investments located in that country. For Beijing, protection of its own citizens residing in Libya was particularly important. For this reason, in February 2011 the Chinese authorities organized the largest overseas evacuation in the history of the PRC: over less than two weeks, almost 36 thousand Chinese citizens have been transported back to their homeland. This was done with the use of both civil and military aircraft and vessels (Li et al., 2015). It is worth mentioning that Beijing sent the new Jiangkai II class guided-missile frigate - "Xuzhou" - of the Chinese People's Liberation Army to Libyan territorial waters, its task being to coordinate the evacuation by sea. It was the second incidence in history of Chinese military presence in the Mediterranean basin, and the first humanitarian mission it conducted there. The efficient evacuation of personnel from Libya was a confirmation of significant development in China's global military capabilities. The experience gained was later used, among others, in March 2015 during evacuation of Chinese workers from war-torn Yemen (Shichor, 2017).

\section{The PRC's Position on Implementation in Libya of the Concept of "Responsibility to Protect"}

The March offensive of government troops resulted in increased violence in Libya. In response, on March 17, 2011, the UNSC adopted Resolution no 1973 on Libya. China, as well as Russia, Brazil, India and Germany abstained from vote. The lack of veto on the part of Beijing and Moscow made it possible to vote in the document. The resolution called on the parties to the conflict for an immediate ceasefire and, above all, putting an end to all military operations against civilians. The UN SC demanded that the Libyan authorities take all feasible steps to protect civilians and provide them with the necessary humanitarian aid. In relation to the international community, it sanctioned the use of necessary measures to defend Libyan civilians and populated areas. One of the solutions adopted in the document was the establishment of a no-fly zone in Libya's airspace, excluding humanitarian aid transports, and the UN member states have been authorized to enforce the ban on flights. The resolution, however, contained an indication that no part of the territory of Libya could be occupied (United Nations, 2011b), which was read as the Security Council denying its approval for ground operations in Libya. 
Resolution 1973 gave the North Atlantic Alliance the legal basis to conduct air operations in Libya. Implementation of a no-fly zone to protect the civilian population was in line with the concept of "Responsibility to protect". Introduction of military sanctions against Libya was not in the interest of the PRC. However, since Beijing had previously supported resolution 1970, it would have been awkward for China to veto another resolution that was de facto its consequence. Above all, however, China could not ignore the position of members of the League of Arab States and the African Union that were in favor of introducing the no-fly zone. The African countries that were then members of the UN Security Council - Nigeria, Gabon and the Republic of South Africa - as well as Lebanon insisted on this solution. Furthermore, among the Arab states were also the UN-designated Protectors in Libya - Saudi Arabia, Jordan, Qatar and the United Arab Emirates, which expressed their readiness to support military operations. On the other hand, Beijing had serious reservations and could not vote in favour of any provisions authorizing an armed operation in Libya (Duggan, 2016). For this reason, the PRC delegation decided to abstain from voting, without blocking the possibility of adoption of this resolution. It was China's concession towards the countries in the region, which in fact could be viewed as undermining the principles traditionally professed in the foreign policy of the Middle Kingdom.

After voting on the resolution, Li Baodong emphasized that China always opposes the use of force in international relations. He also stated that Beijing would continue to support initiatives for the peaceful resolution of the crisis in Libya. The absence of a veto was justified, the ambassador explained, by the great importance China was attaching of the unambiguous position of the Arab League on no-fly zone (Explanation of Vote..., 2011). Beijing has renewed its call for a peaceful dialogue, indicating that this was the best way to resolve the crisis. Li Baodong also praised the diplomatic efforts of the African Union in this regard (Statement by H.E. Ambassador..., 2011a). The Ambassador also referred to the basic principles of the concept of "Responsibility to Protect", including the primary responsibility for the security of citizens being vested in the government of a given state. Involvement of the international community should, in his words, only take place in exceptional circumstances and with maintenance of neutrality. He stressed the that the action of the Security Council should comply with the basic principles of Charter of the United Nations, including respect for sovereignty, independence, unification and territorial integrity of Libya. He particularly emphasized the position that in activities undertaken to protect civilians, one cannot attempt to change the regime or engage in the ongoing civil war on either side (Statement by H.E. Ambassador..., 2011b). 


\section{Opposition of the PRC to NATO Military Operations in Libya}

Between March 23 and October 31, 2011 NATO conducted an air campaign in Libya under the code name "Unified Protector". The operation had three basic objectives - establishing a no-fly zone over Libya, protecting the civilian population from armed attacks and control of compliance with the embargo on delivery of weapons to that country (NATO, 2011). In practice, the coalition of NATO states that carried out the operation, centered around France and the United Kingdom, over-interpreted the mandate of the United Nations. In addition to the pursuing the above objectives, it carried out air attacks against the government forces of Mu'ammar Gaddafi, thereby effectively supporting rebel groups. For this reason, Beijing began to strongly criticize the manner in which the Security Council resolution was being implemented. China protested the shift of civilian protection operations into action intended to change the political regime in Libya (Junbo, Zhimin, 2016). The PRC opposed both the military operations and the accompanying political pressure from NATO states attempting to force Mu'ammar al-Gaddafi to resign from office (Copper, 2016).

In the official Chinese media, NATO's activities in Libya were called "foreign military intervention" leading to "war and chaos". Some of high-ranking state officials even labeled the operations an armed "aggression" and a manifestation of "neocolonialism". They also disseminated the theory that this was a trick of Western leaders aimed at limiting the rapidly growing economic involvement of China in Africa, an attempt to rebuild their own influence in the region (Liu, 2011). At the same time, the PRC criticized the National Transitional Council in Libya (NTC), selected from among the rebels.

Officially, Beijing maintained neutrality in the conflict, claiming that it treated both sides in the same way. According to the Chinese authorities, this neutral position would open for China a multitude of options for action later (Junbo, Méndez, 2015). In practice, however, in the first months of the crisis Beijing supported the al-Gaddafi government. Reports of international organizations indicate that until mid-2011, China provided arms to Libyan governmental troops, thus violating the embargo imposed in February (The Libyan Dilemma..., 2011). As a consequence, some of the rebel groups also targeted the property of Chinese enterprises located in Libya (Olimat, 2014). In this situation, Beijing called on both parties to the conflict to protect Chinese investments, and expressed hope for their continuation after stabilization of the situation in the country (Martina, Buckley, 2011). Documentation discovered since revealed that after the visit of Tripoli officials in Beijing in July 2011, representatives of the Chinese state defense companies were 
ready to sell Libya weapons worth USD 200 million, including missile launchers, anti-tank missiles and portable surface-to-air missile systems (Sotloff, 2012). Due to pressure from the international community and changes in the situation on the Libyan front, the weapons transfer did not take place in the end.

\section{Change of Beijing's Attitude towards the New Libyan Authorities}

Chinese animosity towards the Libyan National Transitional Council was mainly due to concerns about losses in terms of investments made and loans granted, as well as the loss of political connections. The rigid course of action taken up by Beijing carried the risk that after possible victory of the groupings represented in the NTC, China would cease to have any influence in that country. The PRC risked losing a trading partner and had to reckon with a possible loss of up to USD 18 billion invested in infrastructure and assets in Libya (Erian, 2012). Fortunately for Beijing, the support of the Chinese authorities was important for the NTC, which is why it tried to communicate with Beijing at various diplomatic levels. In August 2011, the NTC deputy president Abdel Hafiz Ghoga said that the new government of Libya would respect all contracts concluded by the previous authorities, which was of particular importance to Beijing (Branigan, 2011). In the same month, China delivered humanitarian aid, food and supplies for the rebels to the Benghazi airport. According to the Chinese authorities, however, this maneuver was not a political gesture as the same help was also to be provided to the authorities in Tripoli (Junbo, Méndez, 2015).

On September 16, 2011 the UN Security Council unanimously adopted Resolution No. 2009 setting up the legal basis for post-war stabilization and reconstruction of Libya, as the NATO military operation was to end soon. The document established a United Nations Support Mission in Libya (UNSMIL). This mission of a political character was primarily intended to support the Libyans in the restoration of public order, security and the rule of law, help initiate democratic political and social processes and boost economic recovery (United Nations, 2011c). Beijing decided to support the resolution as it gave the UN a leading role in the efforts to restore Libyan statehood.

Already before the vote on resolution 2009, the Chinese authorities had revised their policy towards Libya and on September 12, 2011 recognized the NTC as the political representation of Libya. It is worth mentioning that Beijing was the last to do so among the permanent members of the UN Security Council (Erdağ, 2017). Nevertheless, at the beginning of 2012 the Chinese and Libyan govern- 
ments established relatively friendly relations. The way for that was paved when, together with its acknowledgement of the NTC, Beijing announced that it respected the decision of the Libyan people to change its government and expressed a desire to strengthen cooperation with Libya. The PRC also declared its aid in the post-war reconstruction of the state. The authorities accepted some losses on the part of Chinese enterprises, expressing hope that the NTC would actually respect previously signed contracts (Junbo, Méndez, 2015). The new government of Libya did not reject the gestures of the Chinese authorities despite their links with the previous regime. The NTC recognized the efforts of Beijing in the field of economic diplomacy and confirmed it would respect international trade agreements signed by the government of Mu'ammar al-Gaddafi.

Chinese companies have been invited by the NTC to return to the Libyan market. Initially they did not receive preferential investment conditions - privileged position was given to enterprises of the states that supported the armed revolution in Libya. Nevertheless, Tripoli and Beijing quickly signed agreements for the sale of Libyan oil to the PRC. For the dynamically developing and thus highly energy-intensive Chinese economy, this was particularly significant (Copper, 2016). In addition, the Libyan authorities offered the PRC large-scale infrastructure contracts to compensate Chinese companies for losses incurred. For example, at the beginning of 2014 China State Construction Engineering Corporation accepted the proposal to build 20,000 houses in Benghazi. Another internal conflict that broke out in Libya in May 2014 stopped this one as well as other investments. After the situation calmed in 2016, a consortium of Chinese enterprises was given the opportunity to invest USD 36 billion in Libya through construction in Tobruk and its surroundings of 10,000 houses, 1 thousand $\mathrm{km}$ of railways, a hospital, a university and other infrastructure (Rogers, 2016). Completion of these flagship investments and other economic ventures of Chinese enterprises in Libya is dependent on development of the political situation and security in that country. Currently, the Libyan authorities want Beijing to become an important local investor and declare its support for political activities for unification of the Libyan state (Xueguan, 2018).

\section{Conclusions}

The Chinese authorities do not have a strategic vision and tactics for dealing with internal conflicts in other states. On the one hand, Beijing tries to remain faithful to the traditional principles of foreign policy, including respect for sovereignty and 
non-interference in internal affairs. On the other hand, the PRC must show some flexibility in order to be able to secure the national economic interests in the event of a change in political regime of a foreign state (Ding, 2016). By allowing the UNSCR 1973 to be adopted, Beijing has to an extent sidestepped its own principles. In addition, China was not neutral during the conflict, initially supporting the regime of Mu'ammar al-Gaddafi and later the NTC. It is also worth noting that China's contribution to the resolution of the Libyan crisis in 2011 was insignificant and essentially limited to diplomatic activities (Junbo, Méndez, 2015).

China's attitude during the crisis confirmed the state's self-perception as a leader among developing countries. However, this is not authoritative leadership, but rather a dominant position resulting from the power of the PRC. Beijing wants regional organizations to have a key say in resolving local crises. In order to be able to claim the mantle of the developing countries' representative in the UN Security Council, China decided to vote against the principles it professed previously (Duggan, 2016). This action was to convince Beijing's partners that promoting the "South-South" concept was worthwhile. China wanted to show that, unlike Western powers, it would not impose its position on others and its leadership would be multilateral.

Not using its veto in vote on the resolution 1973, however, does not mean that China's attitude to military interventions under the "Responsibility to protect" concept without host state consent has changed. The vote on Libya was a consequence of the aforementioned international circumstances. Moreover, the NATO countries going beyond the boundaries of the resolution and using it to change the political regime in Libya was an important lesson for Beijing for the future. China's leaders, similarly as Russian ones, felt deceived by the West (Lanteigne, 2016). This has contributed to the inability to reach international agreement on resolution of further internal conflicts, including the war in Syria (MacDonald, 2016).

It must be said that China approaches the principles of respect for state sovereignty and non-interference in internal affairs in an ambivalent way. If putting emphasis on these values is in the PRC's interest, Beijing is ready to treat them as veritable dogmas. In reality, however, China is ready to show pragmatism, as there are cases of deviation from this line of thinking if only this could push forward Chinese strategic interests - even if the external armed intervention is not a reaction to a humanitarian crisis. Such an example is the Russian military operation in Ukraine since 2014, in which case Beijing has refrained from expressing open criticism as the country wishes to tighten cooperation with Russia, and at the same time Russian activities in Eastern Europe distract the attention of the United States from East Asia (MacDonald, 2016). 
In China's foreign policy economic issues, including the raw materials sector, are of priority importance. In recent years, Beijing has established close cooperation in this domain with a number of regimes seriously violating basic human rights and threatening regional stability, including with Sudan, Angola, Burma, Iran and North Korea. China must reckon with regional integration organizations pressuring it to support the local populations against dictators. Therefore, Beijing should be flexible in its stance towards these regimes to be able to take into account the will of societies in the countries with which it wants to deepen cooperation. At the same time, the Chinese authorities must be very cautious about how they present this issue in their own territory. To maintain its rule, the CCP cannot show ambivalence in relation to rebel activities. Beijing should give a clear message that it can only support such an activity if the political regime commits mass crimes against the populace. The intervention in Libya showed how difficult it is to strike the right balance. On the one hand, Chinese nationalists and some dictators interpreted Beijing's attitude as betrayal of the basic principles of Chinese foreign policy - while on the other hand, the West, the Libyan rebels and societies of many countries in the region perceived the PRC's restraint as tacit assent to crime and contribution to suppression of the democratic movement (Sun, 2012).

If, during future conflicts, China will dogmatize its approach to the principle of non-interference in internal affairs of other states, it may negatively affect the Beijing's international reputation. Refraining from taking a more decisive action in the face of a large-scale humanitarian disaster, serious war crimes or crimes against humanity will undermine China's role as a country contributing to maintenance of global peace and security.

\section{References:}

Branigan, T. (2011). China Looks to Protect its Assets in a Post-Gaddafi Libya. The Guardian. Retrieved from: https://www.theguardian.com/world/2011/aug/23/china-assetspost-gaddafi-libya.

Carvin, S. (2011). UNSC Resolution 1970: Wait, Did the UNJust Kinda Do What it Was Supposed to? Retrieved from: http://duckofminerva.com/2011/03/unsc-resolution-1970wait-did-un-just.html.

Copper, J.F. (2016). China's Foreign aid and Investment Diplomacy. Volume III. Strategy Beyond Asia and Challenges to the United States and the International Order. London-New York: Palgrave Macmillan.

Ding, S. (2016). The Political Rationale of China's Deliberately Limited Role in the Libyan Civil War. In: D. Henriksen, A.K. Larssen (eds.). Political Rationale and International Consequences of the War in Libya (pp. 78-89). Oxford: Oxford University Press. 
Duggan, N. (2016). China's Changing Role in its All-Weather Friendship with Africa. In: S. Harnisch, S. Bersick, J-C. Gottwald (eds.). China's International Roles (pp. 207-225). London-New York: Routledge.

Erdağ, R. (2017). Libya in the Arab Spring. From Revolution to Insecurity. New York: Palgrave Macmillan.

Erian, S. (2012). China at the Libyan Endgame. Policy, 28(1), 49-53. Retrieved from: https://www.cis.org.au/app/uploads/2015/04/images/stories/policy-magazine/2012 -autumn/28-1-12-stephanie-erian.pdf.

Explanation of Vote by Ambassador Li Baodong after Adoption of Security Council Resolution on Libya. (2011). Retrieved from: http://www.china-un.org/eng/hyyfy/t807544.htm.

Falk, R. (2015). Humanitarian Intervention and Legitimacy Wars. Seeking Peace and Justice in the $21^{\text {st }}$ Century. London, New York: Routledge.

Gaudreau, M. (2016). Plurality in China's South South Cooperation: The Case of Rice Projects in Mali. In: H. Cao, J. Paltiel (eds.). Facing China as a New Global Superpower. Domestic and International Dynamics from a Multidisciplinary Angle (pp. 217-237). Singapore: Springer.

Harnisch, S. (2016). China's Historical Self and its International Role. In: S. Harnisch, S. Bersick, J-C. Gottwald (eds.). China's International Roles (pp. 38-58). London-New York: Routledge.

Hoyt, T.D. (2016). US-China Cooperation: The Role of Pakistan After the Death of Osama bin Laden. In: J.H. Ping, B. McCormick (eds.). China's Strategic Priorities (pp. 114-128). London, New York: Routledge.

Junbo, J., Méndez, A. (2015). Change and Continuity in Chinese Foreign Policy: China's Engagement in the Libyan Civil War as a Case Study. London: LSE Global South Unit.

Junbo, J., Zhimin, Ch. (2016). China and the EU in the UN. In: J. Wang, W. Song (eds.). China, the European Union, and the International Politics of Global Governance (pp. 75-94). New York: Palgrawe Macmillan.

Lanteigne, M. (2016). Chinese Foreign Policy. An Introduction. London, New York: Routledge.

Li, M., Kemburi, K.M., Hongzhou, Z. (2015). Growth of China's Power: Capabilities, Perceptions, and Practice. In: M. Li, K.M. Kemburi (eds.). China's Power and Asian Security (pp. 3-24). London, New York: Routledge.

Liu, M. (2011). China's Libya Connection Shows New Kind of Foreign Policy. Daily Beast. Retrieved from: https://www.thedailybeast.com/chinas-libya-connection-shows-newkind-of-foreign-policy?ref=scroll.

MacDonald, A. (2016). Access, Assurance and Acceptance. In: H. Cao, J. Paltiel (eds.). Facing China as a New Global Superpower. Domestic and International Dynamics from a Multidisciplinary Angle (pp. 171-196). Singapore: Springer.

Martina, M., Buckley, Ch. (2011). ChinaUrgesLibya to ProtectInvestments. Retrieved from: https:/www.reuters.com/article/us-china-libya-oil/china-urges-libya-to-protect-invest-ments-idUSTRE77M0PD20110823.

Nathan, A.J. (2009). Principles of China's Foreign Policy. Retrieved from: http://afe.easia. columbia.edu/special/china_1950_forpol_principles.htm.

NATO. (2011). Operation UNIFIED PROTECTOR. Final Mission Stats. Retrieved from: 
http://www.nato.int/nato_static/assets/pdf/pdf_2011_11/20111108_111107-factsheet_up_factsfigures_en.pdf.

Olimat, M.S. (2014). China and North Africa since World War II. A Bilateral Approach. New York: Lexington Books.

Rogers, D. (2016). Chinese Consortium to Invest $\$ 36 b n$ in Libya Infrastructure Bonanza. Retrieved from: http://www.globalconstructionreview.com/news/chinese-consort7ium-inv7est-36bn-liby7an/.

Shichor, Y. (2017). Maximising Output While Minimising Input: Change and Continuity in China's Middle East Policy. In: H.T. Boon (ed.). Chinese Foreign Policy Under Xi (pp. 109-129). London, New York: Routledge.

Sotloff, S. (2012). Chinas Liby'a Problem. The Diplomat. Retrieved from: https://thediplomat.com/2012/03/chinas-libya-problem/.

Statement by H.E. Ambassador Li Baodong, Permanent Representative of China to the United Nations, at the Security Council Briefing on the Situation in Libya. (2011a). Retrieved from: http://www.china-un.org/eng/chinaandun/securitycouncil/regionalhotspots/africa/ t824181.htm.

Statement by H.E. Ambassador Li Baodong, Permanent Representative of China to the United Nations, at the Security Council Open Debate on the Protection of Civilians in Armed Conflict. (2011b). Retrieved from: http://responsibilitytoprotect.org/china(1).pdf.

Sun, Y. (2012). Syria: What China Has Learned From its Libya Experience. Asia Pacific Bulletin, 152, 1-2.

The Libyan Dilemma. (2011). Retrieved from: https://www.economist.com/asia/2011/09/10/ the-libyan-dilemma.

United Nations. (2011a). Resolution 1970 (2011). Adopted by the Security Council at its 6491 ${ }^{\text {th }}$ meeting, on $26^{\text {th }}$ February 2011. Retrieved from: http://www.un.org/en/ga/search/ view_doc.asp?symbol=S/RES/1970(2011).

United Nations. (2011b). Resolution 1973 (2011). Adopted by the Security Council at its 6498 th meeting, on 17 March 2011. Retrieved from: http://www.un.org/en/ga/search/ view_doc.asp?symbol=S/RES/1973(2011).

United Nations. (2011c). Resolution 2009 (2011). Adopted by the Security Council at its $6620^{\text {th }}$ meeting, on 16 September 2011. Retrieved from: http://www.un.org/ga/search/ view_doc.asp?symbol=S/RES/2009\%20\%282011\%29.

Xueguan, M. (2018). Libya Seeks China's Help for Economic Revival and Political Settlement. Retrieved from: http://www.xinhuanet.com/english/2018-02/20/c_136985954. htm.

Zweig, D. (2015). Modelling 'Resource Diplomacy' Under Hegemony: The Triangular Nature of Sino-US Energy Relations. In: D. Zweig, Y. Hao (eds.). Sino-US Energy Triangles. Resource Diplomacy Uunder Hegemony (pp. 19-37). London-New York: Routledge. 